\title{
DOES EFFICIENCY INCREASE THE APPLICATION OF INTEGRATED REPORTING?
}

\author{
Antonija Petrlić ${ }^{1} \&$ Neda Vitezić ${ }^{2}$
}

\author{
UDC / UDK: 657.375:658:316.633(497.5)(497.4) \\ JEL classification / JEL klasifikacija: M14, M4 \\ DOI: https://doi.org/10.22598/pi-be/2020.14.1.51 \\ Preliminary communication / Prethodno prioćenje \\ Received / Primljeno: January 24, 2020 / 24. siječnja 2020. \\ Accepted for publishing / Prihvaćeno za tisak: March 23, 2020 / 23. ožujka \\ 2020 .
}

\begin{abstract}
Summary
Continuous stakeholder demands for more detailed and transparent reporting have led to the development of a new reporting framework. That is the so-called International Integrated Reporting Framework according to which companies report on financial and non-financial aspects of business operations. More importantly, they show the way in which value is created through the established business model in the short, medium, and long term. Since it is still considered a new tool for socially responsible reporting, the question arises of its recognizability and level of its implementation and impact on business operations. Therefore, this paper analytically deals with the overall concept of integrated reporting and its connection with the principle of efficiency as the basis of the value-making process. Therefore, the main objective of the paper was to investigate the current application of the concept of integrated reporting in companies of the Republic of Croatia and the Republic of Slovenia, in the period from 2011 to 2016, and to determine whether a greater degree of business efficiency influences the implementation of integrated reporting methods and socially responsible business operations. The method of online research, descriptive statistics, and non-parametric method of hypothesis testing were used. Although the results showed a low level of application of the International Integrated Reporting Framework, the empirical part shows that a higher level of business efficiency encourages companies to conduct more

\footnotetext{
${ }^{1}$ Antonija Petrlić, MBA, Assistant, University of Rijeka, Faculty of Economics and Business, Ivana Filipovića 4, 51000 Rijeka, Croatia, e-mail: antonija.petrlic@efri.hr ${ }^{2}$ Neda Vitezić, PhD, Full Professor, University of Rijeka, Faculty of Economics and Business, Ivana Filipovića 4, 51000 Rijeka, Croatia, e-mail: neda.vitezic@efri.hr
} 
socially responsible business operations through the presentation of economic, environmental, and social aspects of business operations.

Key words: business efficiency, value added, integrated reporting, Croatia, Slovenia.

\section{INTRODUCTION}

Proper planning, risk avoidance, and making the right business decisions result in efficient operations of every business. That is why, nowadays, direct and indirect shareholders are increasingly demanding transparent and responsible reporting on the financial and social business aspects. In order to meet that requirement and orient on sustainable economy, the so-called Integrated Reporting Framework (hereinafter: IR Framework or IR) was created. The IR Framework is a product of a global association called The International Integrated Reporting Council (hereinafter: IIRC) which forms a global coalition of regulators, investors, companies, standard-setters, the accounting profession, and non-governmental organizations. It was established in August 2010 under the initiative of two bodies: Accounting and Sustainability and Global Reporting Initiative (hereinafter: GRI) (Turturea, 2015). The main mission of the coalition is ,to establish integrated reporting and thinking within mainstream business practice as the norm in the public and private sectors" (The IIRC, 2019). Although the final IR Framework was created by IIRC in 2013, the foundations of its creation go back well before the forming of the Coalition. According to Eccles and Saltzman (2011), the first integrated report was created by the Danish industrial company Novozymes in 2002, followed by the Danish diabetes company Novo Nordisk in 2004, and the Brazilian cosmetics company Natura in 2008. Eccles, Krzus, and Ribot (2015) classified these three companies into the first of four stages of their model of the evolution of integrated reporting, i.e. the so-called "Company Experimentation" stage. They called the other three phases „Expert Commentary“, „Codification“, and „Institutionalization“. However, if one looks back futher, i.e., adheres to the theory that today's business should be based on a socially responsible and sustainable business "that meets the needs of the present without compromising the ability of future generations to meet their own needs" (UN, 1987, p. 34), then the beginnings of integrated reporting do not begin with Novozymes, but long before with Freeman's (1984) stakeholder theory and Elkington's (1997) concept of Tripple Bottom Line (hereinafter: TBL). In the narrowest sense, TBL represents a framework for measuring and reporting of economic goals of a business and the relationship to the environmental and social aspects taking place at the same time The broader understanding includes values, strategy, and application, and is implemented to achieve economic, social and environmental goals set by the company. Over the years, a number of reports have been developed under different names (Roca and Searcy, 2012). However, given the increasingly complex external and internal environment, the increasing volume of direct and indirect stakeholders and their desire to become fully acquainted with all business aspects of a company, a need for more detailed and transparent information emerged. Stakeholders, primarily investors and 
owners (shareholders), realized that only a look at how a company creates value now and in the future can ensure mutual trust, cooperation and effective decision making. Therefore, the IR Framework was developed on the basis of the TBL concept and all the previous voluntary Corporate Social Responsibility (hereinafter: CSR) initiatives and guidelines (GRI guidelines, ISO 26000 and SA 8000 standard, AccountAbility1000 standards, etc.).

The IR Framework represents, ,a concise communication about how an organization's strategy, governance, performance, and prospects, in the context of its external environment, lead to the creation of value over the short, medium and long term" (IIRC, 2013, p. 7). Unlike a CSR report, its primary goal is to explain to investors how a company creates value over time. Moreover, according to Velte and Stawinoga (2016), there are two basic differences between CSR reports and IR reports: the content of the report and the diversity of intentions. Furthermore, CSR reporting is intended for all direct and indirect stakeholders, while the IR Framework is intended primarily for investors, i.e., all stakeholders interested in how a company creates value. In addition, CSR reports provide only information about the economic, environmental, and social aspects of the business, while IR seeks to create a link between the financial, environmental and social aspects of the organization (Reuter and Messner, 2015). Hence, IR also shows the risk evaluation and potential future growth of the company (De Villiers, Rinaldi, and Unerman, 2014).

Figure 1. The Value Creation Process of the IR Framework

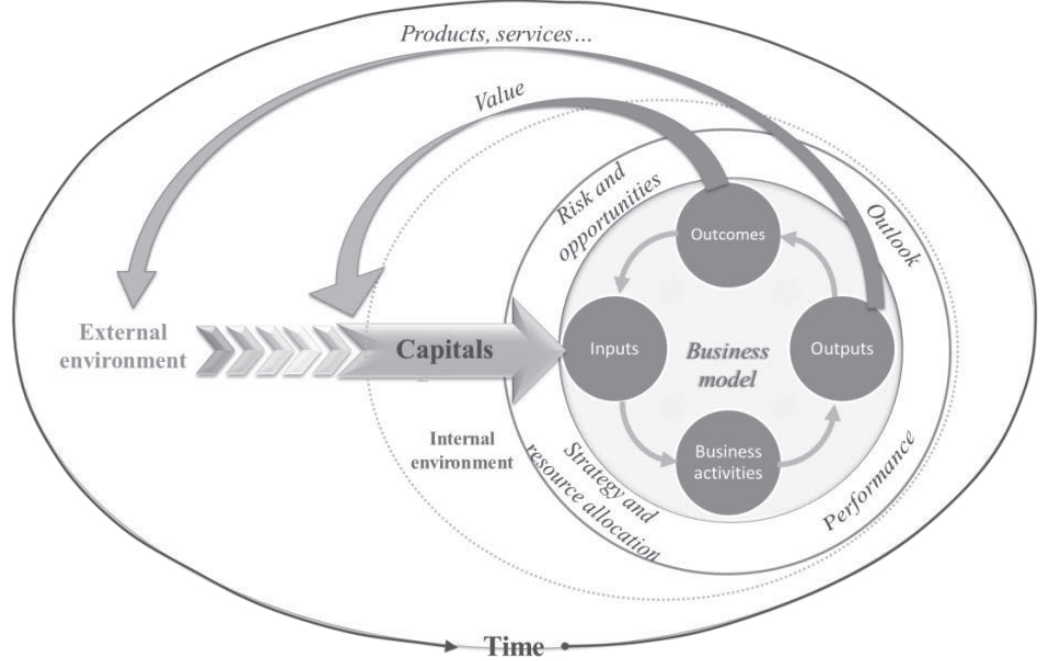

Source: Authors, according to IIRC, 2013, p. 13

The IR report should provide insight into how the company creates value through continuous transformation of all available capitals (financial, manufactured, intellectual, human, social and relationship, and natural) within and outside the company through the implemented business model, taking into account the set strategy 
and resource allocation, identified risks, and opportunities as well as past performance and future outlook. Therefore, the IR Framework as a voluntary reporting method for which individuals have already stated that it could become a report that will completely replace current annual reports (Wild and van Staden, 2013), mandates eight basic, interconnected and non-exclusive parts (IIRC, 2013): 1) organizational overview and external environment, 2) governance, 3) business model, 4) risks and opportunities, 5) strategy and resource allocation, 6) performance, 7) outlook, and 8) basis of preparation and presentation along with the general reporting guidance. Hence, the IR Framework is based on the following seven principles (IIRC, 2013): 1) strategic focus and future orientation, 2) connectivity of information, 3) stakeholder relationships, 4) materiality, 5) conciseness, 6) reliability and completeness, and 7) consistency and comparability. As it is based on a principal approach, it does not propose specific instruments or tools for its implementation (Haller and Van Staden, 2014) and therefore gives the management sufficient freedom in its preparation and creation (Velte and Stawinoga, 2016). The overall purpose of the IR approach is to show ,integrated thinking“ of an organization. According to Simnett and Huggins (2015, cited in Appiagyei, Djajadikerta and Xiang, 2016), integrated thinking should be the outcome of IR that enables organizations to better understand the relationship between their „value drivers and set strategic goals".

Like any other phenomenon, concept, model or theory, the IR Framework has its advantages and disadvantages. However, when considering the sum of disadvantages (Welch, 2013; da Silva Faria, 2016), the explored advantages (IIRC and Black Sun, 2014; AICPA \& CIMA \& BS \& IIRC, 2016), and current applications in practice (Recognized reports, 2019; Johner, 2016), it can be concluded that the IR Framework has in the short term attracted a great deal of attention and support from professional organizations and institutions, individuals and groups. Therefore, it is to be expected that the currently achieved global level of its applicability will only grow. Hence, it is already predicted that it could become the primary report of any, especially large organizations. In addition, in 2017, the European Union issued its own "Guidelines on non-financial reporting" (according to Directive 2014/95/EU), which is based, inter alia, on the IR Framework (EU, 2017) and other frameworks like GRI. According to the Directive 2014/95/EU, beginning on 1 January 2017, all public interest entities, including all companies whose securities are traded on the regulated market, will be required to publish non-financial information, i.e., information on the environmental and social impact of the company (EU, 2014). Furthermore, much research discusses the importance of value added statement (Bagieńska, 2016; Perera-Aldama and Zicari, 2012; Machado, Macedo, and Machado, 2015; EY \& IIRC, 2013) as part of the primary goal of the IR - presentation of how companies create value over time. In order for businesses to create added value for themselves and others, they must satisfy the principle of rationality. Only companies that operate rationally in the short and long term can in the future achieve constant added value, which on the other hand is a criterion for measuring the achieved efficiency. It is fair to say that efficiency and added value are inter-conditioned criteria for measuring the overall performance of a company, and as such, are an essential element of IR. Therefore, the implementation of reports 
containing a more detailed account of how value is created, conditioned by a range of internal and external factors, enables investors and other direct stakeholders to make better business decisions and reduce business risk. It can be emphasized that businesses that operate more efficiently have a greater incentive to fully embrace an integrated reporting method in the context of the economic, environmental, and social requirements of the entire society.

Considering, that the IR Framework has attracted a great deal of attention in a very short time and that the predictions suggest further development, the investigation of its current application and usefulness are of great importance. Hence, growing stakeholders' needs for data transparency and the already confirmed utility and acceptability of the Framework by stakeholders further emphasizes the importance of new research that is still incomplete, but crucial for the development of the Framework and attracting of companies for its application. Although numerous leading practice examples are available on the IIRC website, they mostly come from big corporations. This raises the issue of its application in globally smaller companies from economically smaller countries. Connectivity, the necessity to investigate whether the realized business efficiency influences the application of such a framework, is also an issue.

Accordingly, the aim of this paper is to investigate the application of the IR concept in the companies in the Republic of Croatia and the Republic of Slovenia in the period from 2011 to 2016 and to determine whether a greater degree of business efficiency influences the implementation of integrated reporting methods and corporate social responsibility. By broadely explaining the meaning of the IR Framework, the paper firstly helps understand its concept, and the connection and differences with the other that precede them. Secondly, it expands current knowledge of the level of its application through the example of Croatia and Slovenia and encourages further

discussion. Besides, it shows that new research is needed to provide a broader picture of its application, but to also familiarize companies with the usefulness of IR reporting and corporate social responsibility reporting in general. It is therefore intended for researchers as a call for further studies, and practitioners, i.e., managers as a wake-up call for embracing IR.

The paper is structured in five chapters. Following the introduction, the second chapter presents the literature review on the previous research of IR. The third chapter provides the methodological and data framework. Chapter four presents the results of the conducted analysis, while chapter five contains the conclusion and recommendation for further research.

\section{LITERATURE REVIEW}

Research in the field of integrated reporting is increasing and attracting a growing number of scientists. Its importance and relevance are becoming increasingly prominent due to the numerous corruption scandals, regional and global financial crises, corporate and other institutions failings, climate changes, environmental disasters, etc. An overview of research, limitations, and future implications were provided by Velte 
and Stawinoga (2016). They cite 44 empirical studies that were issued after the final publication of the IIRC Framework in 2013. On the other hand, Dragu and Tiron-Tudor (2014) provided an overview of the studies that preceded the publication of the IIRC Framework, which serve as a basis for selecting a suitable methodology for future integrated reporting research. In addition, Dragu and Tiron-Tudor (2013) confirmed that there is a correlation, albeit low, between voluntary acceptance of an integrated report and political, cultural and economic factors. In its research based on the early adoption phase (2010-2014 reports), Havlová (2015) examined the level of implementation of the IIRC Framework guidelines, the number of reports issued and the level of information on technology utilization. She used 48 companies included in the IIRC IR Pilot Program. The results found that most companies issue one or two reports a year, that more and more companies use interactive online reports, and that listed companies include significantly more information in accordance with the guidelines of the IIRC Framework. Ruiz-Lazano and Tirado-Valencia (2016) explored the level of implementation of the principles of the IIRC Framework within industrial companies that were also part of the IIRC pilot project. Although the results showed a low degree of implementation, this can be justified by the period of the survey. Hence, the reports that were taken into the sample were actually the first IR reports created. More specifically, these were the reports of 21 companies issued in the years 2013 and 2014. Although other authors have done similar research (Chersan, 2015; Sofian, 2016), so far limited research has addressed the successful trends of the application of the IR Framework, i.e., mostly for African companies (Haji and Anifowose, 2016; Sukhari and De Villiers, 2018; Marrone and Oliva, 2019, etc.). This is attributed to the fact that South Africa was the first to introduce integrated reporting as an obligation for companies listed on the Johannesburg Stock Exchange. Through a systematic literature review, Vitolla, Raimo, and Rubino (2019) concluded that the content and quality of integrated reporting and its impact on financial and non-financial (such as environmental, social, and governance) performance need further investigation. They also emphasize the importance of analysing the relationship between integrated reporting and integrated thinking, as no studies have been conducted yet. In 2019 Vitolla et al. proved that integrated reporting quality has a significant, but negative effect on the equity capital cost. By investigating 116 international companies classified as "Leading Practices" of the IIRC Framework in 2016, they showed that there is a difference between the adoption of IR, the level of its incorporation, and the quality of published IR reports, and between reporting quality and information quality. They highlighted that managers can reduce the cost of equity capital by providing ,integrated reports containing significant information that can satisfy investors' information needs and influence their decisions and behavior" (Vitolla et al., 2019, p. 8). This is ultimately the main purpose of an integrated report - informed investors. Furthermore, some authors have studied and confirmed the interdependence, i.e. the positive correlation between non-financial reporting and reputation (Roth, 2014, cited in Moolman, Oberholzer, and Steyn, 2016), as well as the influence of culture on its application (Vitolla et al., 2019; Raimo, Zito, and Caragnano, 2019). 
Of course, as in all other fields, there are critics (Solomon and Maroun, 2012, Milne and Gray, 2013, Brown and Dillard, 2014 cited in Haji and Anifowose, 2017; Flower, 2015) who focus their research skills on refuting the proven positive impacts of IR. Hence, they argue that there is still insufficient evidence to support that the IIRC Framework implementation influences organizational change in reporting and that, compared to previous guidelines (e.g. GRI), the IIRC Framework concept is highly regressive, i.e., that it has a limited and one-sided approach to assessment and reporting on sustainable issues.

Although some other studies are addressing the quality of integrated reporting, its level of implementation, and its impact on individual stakeholders or company characteristics, the ones that are most relevant to the research that will be presented in this paper are those focused on the relationship between business performance and the degree of implementation of the integrated reporting concept and socially responsible behavior. Hence, over the past three decades, a lot of studies have dealt with this issue. Waddock and Graves (1997) confirmed the correlation between CSR and financial performance of a business, using the return on assets (ROA), return on equity (ROE), and profit margin as performance benchmarks, corporate social performance index as the dependent variable, and total assets, total sales, number of employees, and debt relative to total assets as control variables. Similar research was conducted by Weber et al. (2008). However, they used ROA, ROE, profit before interest, taxes, and depreciation (EBITDA), and total return on shares (TRS) for efficiency variables, while using the calculated GRI index as the independent variable. The results confirmed that companies with good GRI indicators also had good efficiency indicators except for TRS, which proved to be non-significant. Abreu, Almeida, and Lopez (2017) also confirmed that companies that disclose their CSR information have higher financial performance, i.e., ROA, ROE, earnings before interest and taxes (EBIT), and EBITDA. Chen, Feldmann, and Tang (2015) came to the conclusion that it is highly likely that companies that have good GRI indicators will also have good financial results, but only in terms of ROE. Sales growth and cash flow relative to sales have proven to be insignificant, which the authors attributed to the fact that profitable companies have additional sources of advancement for CSR, backing the conclusions reached by Waddock and Graves (1997). Mc Williams and Siegel (2000, 2001) concluded that there is neither a clear positive nor a clear negative relationship between CSR and financial performance. On the other hand, the relationship between CSR and performance in the context of a positive correlation of CSR strength and a negative correlation of CSR ratio to the dependent variable performance expressed in sales, ROA and ROE, was confirmed by Alikaj, Nguyen, and Medina (2017). Besides, they confirmed that these ties are stronger when it comes to multinational companies rather than a domestic company in the USA. Similar studies were conducted by Margolis and Walsh, and Orlitzky et al. in 2003, Allouche and Laroche in 2005, and Beurden and Gössling in 2008 (cited in Oshika and Saka, 2017). Hence, Johari and Komathy (2019) proved that, in Malaysia, companies' sustainability reporting has a significant effect on performance, i.e., ROA. However, there is very little research on these interdependencies in the context of the implementation of the IR Framework. Churet 
and Eccles (2014), in collaboration with RobecoSAM, an expert company in the field of sustainable investments and one of the largest databases of financially significant sustainability information, have tried to prove that companies using integrated reporting will have better financial results. As a measure of financial efficiency, they used Return on Investment Capital. The correlation of the total sample was only confirmed within two sectors, health and information technology, but with a very small sample significance. They attributed these results to the fact that integrated reporting is a relatively young concept and that, as in the previous adoption of the sustainability report, there are some time delays in its effects. Churet and Eccles (2014) also point that in 2011 , in its own study, RobecoSAM was able to confirm a positive correlation between sustainability and financial performance. Furthermore, they highlight that in 2013 Eccles and Serafeim confirmed that companies with better financial performance were more likely to accept the idea of producing integrated reports, while in a survey conducted in 2011 together with Ioannou, they confirmed that companies with superior environmental, social and corporate governance (ESG) management also have much more transparent external reports focused on ESG issues contributing to better financial results. Buallay (2019) proved that EGS, i.e., sustainability reporting has a significant positive effect on operational and financial performance in the European banking sector, while Adegboyegun et al. (2020) proved that in the Nigeria banking industry IR only has a long-term relationship with corporate performance. Turturea (2015) confirmed that integrated reporting helps companies achieve better financial results using only the report of one company (Novo Nordisk), while Appiagyei, Djajadikerta, and Xiang, (2016) based the same conclusion upon South African and Australian companies. By using 65 South African "Leading Practices" reports of the IIRC online database, Marrone and Oliva (2019) proved that companies' profitability, expressed through ROE, positively influences the level of compliance with the IIRC framework. The existence of a positive effect of integrated reporting on corporate performance measured through ROA was also confirmed by Affan (2019) on the chemical industry sectors of Indonesia in 2017. The interesting part is that the study included companies that have not fully adopted the IR framework and were under no regulatory disclosure requirements therefor. It can be emphasized that further measurements could additionally improve the given results. Dees (2019) proved a positive and significant relationship between the publication of integrated reports and long-term financial performance (Tobin's Q) and a positive, but insignificant relationship with short-term financial performance (ROA). Lopes and Coelho (2018) considered earnings as an important indicator of the ability to create value, and therefore used EBIT as a proxy in proving that firms with obligatory IR reporting are less profitable than those that do it voluntarily. Furthermore, Wen and Kiew Heong (2017) and Albetairi, Kukreja, and Hamdan (2018) investigated the content elements of IR, i.e., how the level of their disclosures influence financial performance. Although through different results, both models proved the existence of a significant impact of the elements on ROA and ROE. Thus, both models proved a significant positive effect of the Business Model discourse on ROA. On the other hand, Suttipun (2017) proved that capital disclosure has a significant effect on corporate financial performance (Tobin's Q). Nevertheless, some studies denied the influence of 
integrated reporting on performance (Hurghiş, 2015; Dube, 2017; Matemane and Wentzel, 2019; Sofian, 2019). The studies used different variables for firm performance measurement, like ROA, ROE, earnings per share (EPS), firms portfolios, Tobin's Q, and economic value added. Thus, only Matemane and Wentzel (2019) who used four of the indicators proved that EPS has a relationship with integrated reporting quality.

The research presented in this paper is based on the individual elements of the above-exemplified empirical studies, but above all on the research conducted by Vitezić (2010, 2011) and Vitezić and Petrlić (2018) on the example of the Republic of Croatia, in which the positive relationship between the achieved level of business efficiency and corporate social responsibility was confirmed. The research hypothesis of this study is that improved business efficiency of companies influences the implementation of integrated reporting methods and corporate social responsibility.

\section{RESEARCH METHODOLOGY}

To determine the extent to which Croatian and Slovenian companies have recognized the IR Framework, and confirm or reject the hypothesis that improved business efficiency of companies has an influences the implementation of integrated reporting methods and corporate social responsibility, an empirical study was conducted on a sample of 161 companies in the period from 2011 to 2016. The sample included companies whose securities were listed on the Zagreb Stock Exchange and the Ljubljana Stock Exchange as well as companies registered as members of the Croatian Business Council for Sustainable Development (HR BCSD) on December 13, 2017. Although the initial sample included a total of 199 companies, 165 companies from the Zagreb Stock Exchange and HR PSOR members ( 37 members) and 34 companies from the Ljubljana Stock Exchange, in accordance with previous studies and because of the comparability of the data, banks, insurance companies, investment funds, ministries, cities, companies in liquidation and bankruptcy, higher business schools and colleges were excluded from the sample. Companies which were missing financial data that were established after 2011 or changed their name during the observed period were also excluded. Hence, the final sample consists of 27 Slovenian and 134 Croatian companies.

In accordance with the set goals, i.e., empirical research questions, the data collection process consisted of the following two steps:

- To what extent have Croatian and Slovenian companies recognized the Global Integrated Reporting Framework? - The latest available report of each company was reviewed through the company's website, or Croatian Annual Financial Statements Registry (RGFI), and the Agency of the Republic of Slovenia for Public Legal Records and Related Services (AJPES).

- Does improved business efficiency influence the implementation of integrated reporting methods and corporate social responsibility? - Consolidated and non-consolidated financial data were collected for the period of six years 
through the Amadeus Bureau van Dijk database, supplemented by insufficient data through the RGFI and AJPES.

Due to the availability and the way of recording the data within the Amadeus Bureau van Dijk database, the sample consists of 31 companies with consolidated financial data and 130 companies with non-consolidated data. Croatian companies include data on a consolidated (31) and non-consolidated (103) basis, while Slovenian companies have only non-consolidated data.

Various qualitative and quantitative methods were used to process and present the research results. In order to answer the first question, a secondary method was used i.e. online research and appropriate analytical data processing methods (e.g. the analysis and synthesis method, classification method, compilation method). Furthermore, mathematical and statistical methods, namely the descriptive statistics method, and the non-parametric Mann-Whitney $U$ test were used to analyze the impact of efficiency, i.e., to answer the second research question. The Shapiro-Wilk test was used for normality testing of data and Levene's test for variance homogeneity. The software tools used to process the data were Microsoft Excel and Stata 14.

\section{RESULTS AND DISCUSSION}

By examing the reports of the companies in the sample (Table 1), it can be emphasized that Croatian and Slovenian companies have not recognized the IR Framework so far. This is consistent with two basic facts: that the concept is relatively new and being applied on a voluntary basis. It is fair to say that some of its elements have been recognized by individual companies, but that reporting in this sample is still based on the TBL concept.

Table 1. The Number of Reports According to Basis of Preparation

\begin{tabular}{|c|l|l|l|}
\hline \multirow{2}{*}{ Basis of preparation } & \multicolumn{2}{|c|}{ Country } & \multirow{2}{*}{ Total } \\
\cline { 2 - 3 } & Croatia & Slovenia & \\
\hline WITHOUT IR & 111 & 13 & 124 \\
\hline Consolidated financial data & 19 & - & 19 \\
\hline Non-consolidated financial data & 92 & 13 & 105 \\
\hline GRI & 15 & 2 & 17 \\
\hline Consolidated financial data & 10 & - & 10 \\
\hline Non-consolidated financial data & 5 & 2 & 7 \\
\hline IIRC \& GRI & - & 1 & 1 \\
\hline Non-consolidated financial data & - & 1 & 1 \\
\hline OWN FORM & 8 & 11 & 19 \\
\hline Consolidated financial data & 2 & - & 2 \\
\hline Non-consolidated financial data & 6 & 11 & 17 \\
\hline Total & 134 & 27 & 161 \\
\hline Source: Authors & & & \\
\hline
\end{tabular}

Source: Authors 
More specifically, the companies reporting outside the financial frameworks do it in accordance with the GRI guidelines or according to their own CSR form. The exception is a single Slovenian company (Gorenje d.d.) that prepared its annual report (for 2016) according to the IR Framework and the GRI guidelines. Of Croatian companies, there is one company (Valamar Riviera d.d.) for which it is fair to say that it compiled its report following the guidelines of the IIRC Framework, although they did not specify it. The companies that don't include all three TBL aspects (economic, environmental, and social) and are oriented only to financial reporting, are categorized as companies without integrated reporting.

A total of 37 or $23 \%$ of companies do not only include financial, but also economic, environmental, and social aspects of their business in their reports. Most companies, 124 or $77 \%$, still report only on the basis of the classic annual, i.e., financial report which mainly includes audit reports. Companies that include sustainable business aspects are mostly very large or large, and some are medium-sized. As noted above, few of the companies have identified some elements of IR Framework and included them in their reports compiled on the basis of the TBL concept. Looking at only the part of the sample that includes companies with GRI and own formed reports, the following elements and ways of publishing them can be recognized:

- Risk - individual companies use a detailed description of the identified risks and sub-risks, with tabulations of their areas, methods of removal, probability of occurrence, and severity of impact. Others, however, present a risk management model (both descriptive and graphic), and several include thermal risk matrices.

- Stakeholders - almost half of the companies (16) have clearly displayed stakeholders directly or indirectly involved in their operations, while for the remaining companies it can only be assumed depending on the areas presented in the reports.

- Materiality - for example, only 6 companies use the materiality matrix to show the importance of the most prominent aspects of the business. In addition, some of them associate each identified aspect of significance with stakeholders and companies within the group, with the type of stakeholders and the importance of influencing them.

- Added Value - most companies (11) that compile their reports in accordance with the GRI guidelines show added value in accordance with the GRI indicator „Retained Economic Value“. These are mostly Croatian companies, while Slovenian companies most often use value added per employee calculated as the sum of earnings before interest, taxes, depreciation, and amortization and employee costs, or added value calculated as net sales plus capitalized own products and services and other revenues, less costs of materials, goods, and services and other operating expenses.

Overall, Croatian companies have accepted GRI reporting to a larger extent than Slovenian companies; however, only one Slovenian company has a report created in accordance with the IR Framework. With regard to the involvement of some of the 
above elements, i.e., characteristics of the IR Framework, it is evident that Croatian companies have been using it much more, except for risk analysis, in which Slovenian companies are leading due to the use of risk matrices and detailed tables with risk descriptions.

According to the presented literature review (Chapter 2), it can be concluded that authors have a different understanding of integrated reports. For example, Eccles and Saltzman (2011), and Eccles, Krzus, and Ribot (2015) consider reports made upon the TBL concept also a kind of an integrated report. Therefore, in accordance with these and the previously obtained results of acceptance of the IR Framework in Croatian and Slovenian companies, but for the purpose of answering the second research question of this study, two company groups were created - one with integrated reporting and one without. Since reporting in Croatian and Slovenian companies is mostly still based on a narrow understanding of the TBL concept, in this empirical part of the research integrated reporting will include those reports that cover economic, environmental, and social aspects of a business. More precisely, they will include reports prepared according to the GRI guidelines, own CSR guidelines, and the one that applies the IIRC Reporting Framework.

Therefore, the following five efficiency indicators were selected for hypothesis testing:

1) Return on assets (ROA) calculated as net income divided by total assets,

2) Return on equity (ROE) calculated as net income divided by shareholder funds,

3) Earnings before interest and taxes (EBIT) calculated as all operating revenues minus all operating expenses, i.e., gross profit minus other operating expenses,

4) Earnings before interest, taxes, depreciation, and amortization (EBITDA) calculated as EBIT plus depreciation and amortization,

5) Profit margin (PM) calculated as profit before tax divided by operating revenue.

Based on the results (Table 2) of descriptive statistics it can be concluded that, on average, companies that use integrated reporting have better performance on all selected performance indicators than those that have not yet adopted the concept or are only applying it to a minimum. For example, the average ROA for companies with integrated reporting is $2.3 \%$, while for companies that have not accepted it, it is only $0.3 \%$. The PM for companies using the integrated reporting method averages $4.5 \%$, while for the other group of companies it is negative, indicating that a large number of these companies operated at a loss for the period. In addition, EBIT, as one of the most commonly used indicators, is more than twenty times higher with the application of integrated reporting than those without it. On average, total assets are almost eight times higher, while capital and reserves are ten times higher with integrated reporting companies. Besides, the calculated medians also show that companies that use integrated reporting have better performance on all five selected indicators. 
Table 2. Descriptive Statistics of the Total Sample

\begin{tabular}{|c|c|c|c|c|c|c|}
\hline Variable & $\begin{array}{l}\text { Number of } \\
\text { observations }\end{array}$ & Mean Value & $\begin{array}{c}\text { Median } \\
\text { Value }\end{array}$ & $\begin{array}{l}\text { Standard } \\
\text { deviation }\end{array}$ & Minimum & Maximum \\
\hline \multicolumn{7}{|c|}{ Total sample } \\
\hline ROA & 966 & 0.7290166 & 0.875 & 10.96945 & -71.46 & 86.29 \\
\hline ROE & 966 & -4.176056 & 1.56 & 58.20535 & -858.1 & 219.04 \\
\hline EBIT & 966 & 68504.3 & 5892.055 & 329268.4 & -1712000 & 3200449 \\
\hline EBITDA & 966 & 180770 & 19912.17 & 614219.8 & -432150.3 & 6935000 \\
\hline $\mathrm{PM}$ & 966 & -3.569068 & 1.48 & 100.1461 & -3015 & 99.06 \\
\hline \multicolumn{7}{|c|}{ Companies with integrated reporting } \\
\hline ROA & 222 & 2.293739 & 2.305 & 7.297515 & -61.87 & 17.91 \\
\hline ROE & 222 & -0.4172523 & 4.42 & 49.44494 & -486.06 & 54.56 \\
\hline EBIT & 222 & 258745.3 & 80173.69 & 594079.7 & -1712000 & 3200449 \\
\hline EBITDA & 222 & 645246.7 & 168930.8 & 1133381 & -426481.2 & 6935000 \\
\hline $\mathrm{PM}$ & 222 & 4.489189 & 3.775 & 10.97868 & -62.41 & 38.86 \\
\hline \multicolumn{7}{|c|}{ Companies without integrated reporting } \\
\hline ROA & 744 & 0.2621237 & 0.53 & 11.81067 & -71.46 & 86.29 \\
\hline ROE & 744 & -5.297634 & 0.88 & 60.55946 & -858.1 & 219.04 \\
\hline EBIT & 744 & 11738.83 & 2426.64 & 147630.2 & -822001.5 & 2644947 \\
\hline EBITDA & 744 & 42176.11 & 10409.26 & 155607.4 & -432150.3 & 2646346 \\
\hline PM & 744 & -5.973548 & 0.99 & 113.8632 & -3015 & 99.06 \\
\hline
\end{tabular}

Source: Authors

In order to test the set hypothesis, the data were firstly tested for normality of distribution and homogeneity of variances by Shapiro-Wilk and Levene's tests. As the tests confirmed a non-normal distribution $(\mathrm{z}<0,05)$ and presence of unequal data variances $(F>0,05)$, the non-parametric Mann-Whitney $U$ test was performed for hypothesis testing between the independent samples. A p-value $<0.05$ was considered to be statistically significant.

Table 3. Test of Significance of the Total Sample

\begin{tabular}{|c|r|r|r|r|r|c|}
\hline \multirow{2}{*}{ Var. } & \multicolumn{2}{|c|}{ Rank Mean } & \multicolumn{2}{c|}{ Rank Sum } & \multicolumn{2}{c|}{ Mann-Whitney test } \\
\cline { 2 - 8 } & With IR & Without IR & With IR & Without IR & \multicolumn{1}{c|}{ Z } & \multicolumn{1}{c|}{ Sig. } \\
\hline ROA & 573.66 & 456.60 & 127352.5 & 339708.5 & -5.486 & 0.0000 \\
\hline ROE & 581.97 & 454.12 & 129197.5 & 337863.5 & -5.992 & 0.0000 \\
\hline EBIT & 701.72 & 418.39 & 155782 & 311279 & -13.279 & 0.0000 \\
\hline EBITDA & 744.48 & 405.63 & 165275 & 301786 & -15.881 & 0.0000 \\
\hline PM & 568.22 & 458.22 & 126144 & 340917 & -5.155 & 0.0000 \\
\hline
\end{tabular}

Source: Authors

The results of the Mann-Whitney $U$ test (Table 3) confirm that there is a statistically significant $(<0,05)$ difference between companies with IR and those without considering all the chosen performance indicators. Besides, the rank means of all indicators are higher in the companies with IR. It can therefore be emphasized that companies with IR have higher business efficiency, i.e., that they will be more 
encouraged to adopt an IR reporting system. Thus, the set hypothesis that improved business efficiency of companies influences the implementation of integrated reporting methods and corporate social responsibility can be accepted.

Given that the total sample consists of consolidated and non-consolidated financial data, descriptive statistics and testing were also conducted by combining the two created groups, i.e., companies with consolidated data that use integrated reporting and those that do not, and companies with non-consolidated data that apply and do not apply it.

Table 4. Median values of descriptive statistics and test of significance of consolidated and non-consolidated data by the condition of integrated reporting (IR) application

\begin{tabular}{|c|c|c|c|c|c|c|c|c|}
\hline \multirow[b]{2}{*}{ Var. } & \multicolumn{2}{|c|}{ Median Value } & \multicolumn{2}{|c|}{ Rank Mean } & \multicolumn{2}{|c|}{ Rank Sum } & \multicolumn{2}{|c|}{ Mann-Whitney } \\
\hline & $\begin{array}{l}\text { With } \\
\text { IR }\end{array}$ & Without IR & With IR & $\begin{array}{c}\text { Without } \\
\text { IR }\end{array}$ & $\begin{array}{l}\text { With } \\
\text { IR }\end{array}$ & Without IR & Z & Sig. \\
\hline \multicolumn{9}{|c|}{ Consolidated (No. of observation: With $I R=72 ;$ Without $I R=114$ ) } \\
\hline ROA & 3.83 & 0.09 & 117.42 & 78.39 & 8454.00 & 8937.00 & -4.815 & 0.0000 \\
\hline $\mathrm{ROE}$ & 6.955 & 0.275 & 118.18 & 77.91 & 8509.00 & 8882.00 & -4.969 & 0.0000 \\
\hline EBIT & 122978.7 & 13205.61 & 127.82 & 71.82 & 9203.00 & 8188.00 & -6.909 & 0.0000 \\
\hline EBITDA & 281285.5 & 65182 & 135.40 & 67.04 & 9749.00 & 7642.00 & -8.436 & 0.0000 \\
\hline PM & 4.375 & 0.21 & 114.33 & 80.35 & 8231.50 & 9159.50 & -4.193 & 0.0000 \\
\hline \multicolumn{9}{|c|}{ Non-consolidated (No. of observation: With IR=150; Without IR=630) } \\
\hline ROA & 1.37 & 0.64 & 441.92 & 378.26 & 66288.00 & 238302.00 & -3.110 & 0.0019 \\
\hline ROE & 2.94 & 0.985 & 446.94 & 377.06 & 67040.50 & 237549.50 & -3.414 & 0.0006 \\
\hline EBIT & 51438.88 & 2284.38 & 563.29 & 349.36 & 84493.00 & 220097.00 & -10.451 & 0.0000 \\
\hline EBITDA & 113219.3 & 8912.97 & 597.03 & 341.33 & 89555.00 & 215035.00 & -12.492 & 0.0000 \\
\hline PM & 2.665 & 1.09 & 447.93 & 376.83 & 67189.00 & 237401.00 & -3.474 & 0.0005 \\
\hline
\end{tabular}

Source: Authors

The results in Table 4 also confirm the set hypothesis in terms of the basis of preparation of the financial statements. All indicators have significantly better median values in case where the integrated reporting method is applied. The results of the Mann-Whitney $U$ test $^{3}$ confirm a statistically significant $(<0,05)$ difference between the two groups by all the indicators and show significantly higher rank means by those that apply IR. Furthermore, the difference in results was also analyzed depending on the reporting guidelines applied, GRI or own guidelines, and on the basis of their preparation.

\footnotetext{
${ }^{3}$ Shapiro-Wilk and Levene's tests confirmed a non-normal distribution and presence of unequal variances.
} 
Table 5. Median values of descriptive statistics and test of significance by type of guidance applied, without and with the condition of financial database preparation

\begin{tabular}{|c|c|c|c|c|c|c|c|c|}
\hline \multirow{2}{*}{ Var. } & \multicolumn{2}{|c|}{ Median Value } & \multicolumn{2}{|c|}{ Rank Mean } & \multicolumn{2}{|c|}{ Rank Sum } & \multicolumn{2}{|c|}{ Mann-Whitney } \\
\hline & GRI & Own & GRI & Own & GRI & Own & $\mathrm{Z}$ & Sig. \\
\hline \multicolumn{9}{|c|}{ Consolidated + Non-consolidated (No. of observation: $G R I=102 ;$ Own $=114$ ) } \\
\hline ROA & 4.07 & 1.005 & 131.46 & 87.96 & 13409.00 & 10027.00 & 5.107 & 0.0000 \\
\hline ROE & 7.12 & 2.19 & 128.84 & 90.30 & 13141.50 & 10294.50 & 4.524 & 0.0000 \\
\hline EBIT & 125915.8 & 32244.51 & 129.67 & 89.56 & 13226.00 & 10210.00 & 4.708 & 0.0000 \\
\hline EBITDA & 297083 & 82395.31 & 136.57 & 83.39 & 13930.00 & 9506.00 & 6.244 & 0.0000 \\
\hline PM & 5.425 & 1.69 & 123.56 & 95.03 & 12603.00 & 10833.00 & 3.350 & 0.0008 \\
\hline \multicolumn{9}{|c|}{ Consolidated (No. of observation: GRI=60; Own=12) } \\
\hline ROA & 3.985 & 0.905 & 38.38 & 27.08 & 2303.00 & 325.00 & 1.707 & 0.0877 \\
\hline ROE & 7.26 & 2.615 & 37.76 & 30.21 & 2265.50 & 362 & 1.141 & 0.2539 \\
\hline EBIT & 139764.5 & 27789 & 40.43 & 16.83 & 2426.00 & 202.00 & 3.566 & 0.0000 \\
\hline EBITDA & 350982 & 96674 & 41.68 & 10.58 & 2501.00 & 127.00 & 4.699 & 0.0000 \\
\hline PM & 4.675 & 1.005 & 38.57 & 26.17 & 2314.00 & 314.00 & 1.874 & 0.0610 \\
\hline \multicolumn{9}{|c|}{ Non-consolidated (No. of observation: $G R I=42 ; O w n=102$ ) } \\
\hline ROA & 4.615 & 1.085 & 93.32 & 63.93 & 3919.00 & 6520.50 & 3.844 & 0.0001 \\
\hline ROE & 6.85 & 2.095 & 90.93 & 64.91 & 3819.00 & 6621.00 & 3.402 & 0.0007 \\
\hline EBIT & 86579.05 & 32244.51 & 84.19 & 67.69 & 3536.00 & 6904.00 & 2.158 & 0.0309 \\
\hline EBITDA & 186362 & 66732.48 & 90.29 & 65.18 & 3792.00 & 6648.00 & 3.283 & 0.0010 \\
\hline PM & 6.4 & 1.745 & 85.95 & 66.96 & 3610.00 & 6830.00 & 2.483 & 0.0130 \\
\hline
\end{tabular}

Source: Authors

The results in Table 5 show that companies reporting according to GRI guidelines have much better results, i.e., median values measured by selected indicators than those that prepare their reports according to their own CSR form. It can be assumed that companies that would raise their reports in the future to the level of an IR Framework report could be even more successful given the width of the achieved results that the tracking option enabled through specific elements and principles of the Framework. This is only not the case with ROA, ROE, and PM by consolidated data, given that the Mann-Whitney $U$ test ${ }^{4}$ confirms their non-significance $(p>0,05)$.

Moreover, a similar conclusion can be drawn by comparing companies with and without integrated reporting in Croatia and Slovenia (Table 6). Although all indicators (except ROA for Slovenian companies) have higher median values in companies with IR, the Mann-Whitney $U$ test ${ }^{5}$ also confirmed non-significance $(\mathrm{p}>0,05)$ of ROA, ROE, and PM for Slovenian companies. We can therefore conclude

\footnotetext{
${ }^{4}$ Shapiro-Wilk and Levene's tests confirmed a non-normal distribution and presence of unequal variances.

${ }^{5}$ Shapiro-Wilk and Levene's tests confirmed a non-normal distribution and presence of unequal variances.
} 
that improved business efficiency influences the implementation of integrated reporting methods and corporate social responsibility, but that it is not as significant as in Croatia.

Table 6. Median values of descriptive statistics and test of significance between countries by the condition of integrated reporting (IR) application

\begin{tabular}{|c|c|c|c|c|c|c|c|c|}
\hline \multirow{2}{*}{ Var. } & Median Value & \multicolumn{2}{c|}{ Rank Mean } & \multicolumn{2}{c|}{ Rank Sum } & \multicolumn{2}{c|}{ Mann-Whitney } \\
\cline { 2 - 9 } & $\begin{array}{c}\text { With } \\
\text { IR }\end{array}$ & Without IR & With IR Without IR & $\begin{array}{c}\text { With } \\
\text { IR }\end{array}$ & Without IR & Z & Sig. \\
\hline \multicolumn{8}{|c|}{ Croatia (No. of observation: With IR=138; Without IR=666) } \\
\hline ROA & 2.995 & 0.36 & 498.30 & 382.65 & 68765.00 & 254845.00 & -5.324 & 0.0000 \\
\hline ROE & 5.295 & 0.6 & 505.41 & 381.18 & 69746.00 & 253864.00 & -5.720 & 0.0000 \\
\hline EBIT & 59054.5 & 2227.135 & 570.88 & 367.81 & 78782.00 & 244828.00 & -9.358 & 0.0000 \\
\hline EBITDA & 151976.5 & 10046.14 & 625.72 & 356.25 & 86350.00 & 237260.00 & -12.406 & 0.0000 \\
\hline PM & 4.375 & 0.83 & 480.16 & 386.41 & 66262.00 & 257348.00 & -4.316 & 0.0000 \\
\hline \multicolumn{8}{|c|}{ Slovenia (No. of observation: With IR=84; Without IR=78) } \\
\hline ROA & 1.37 & 1.465 & 81.14 & 81.89 & 6815.50 & 6387.50 & 0.102 & 0.9186 \\
\hline ROE & 3.12 & 2.26 & 84.05 & 78.75 & 7060.50 & 6142.50 & -0.719 & 0.4721 \\
\hline EBIT & 95654.87 & 4331.915 & 109.70 & 51.13 & 9215.00 & 3988.00 & -7.941 & 0.0000 \\
\hline EBITDA & 264364.8 & 14731.82 & 110.99 & 49.74 & 9323.00 & 3880.00 & -8.303 & 0.0000 \\
\hline PM & 2.395 & 1.5 & 87.58 & 74.95 & 7357.00 & 5846.00 & -1.713 & 0.0867 \\
\hline
\end{tabular}

Source: Authors

It can be pointed out that the presented study results generally confirm the hypothesis that higher efficiency encourages companies to implement an integrated reporting method, which consequently allows for a more complex assessment of business performance, but also reduces stakeholder risk. As a rule, companies with higher efficiency are more inclined to environmental and social sustainability components and are thus more socially responsible. It can be assumed that, due to the achieved efficiency level, these companies, which are mostly very large, have a greater possibility for financing environmental and social aspects, and thus for monitoring the achieved results through the implementation of integrated reporting.

\section{CONCLUSION AND FURTHER RESEARCH}

Given that the IR Framework is one of the tools for achieving corporate social responsibility, and that companies should base their overall management system on sustainable development, its visibility in global and domestic contexts become an important issue. When it comes to its recognition within Croatian and Slovenian companies, it can be concluded that it has not yet been accepted. It is fair to say that only some of its elements have been applied to a certain extent. This conclusion was obtained by the empirical study, conducted on the sample of 161 Croatian and Slovenian companies in the period from 2011 to 2016. Only one company in the sample 
had a report created in accordance with the IR Framework, while others still create them mainly on a narrower understanding of the concept of TBL, i.e., based on GRI guidelines or their own CSR form. Nevertheless, the statistical analysis of selected efficiency indicators and created groups of companies, with and without an integrated reporting method, confirmed that higher levels of companies' efficiency performance encourage the implementation of integrated reporting and socially responsible behavior. Companies with higher efficiency are generally more committed to environmental and social sustainability components and thus more socially responsible. This was confirmed on the basis of the total sample, consolidated and non-consolidated reporting data, and partially for companies within Croatia and Slovenia. It has also been confirmed that companies reporting according to the GRI guidelines have much better results measured by selected indicators than those that report according to own CSR report forms, with the exception of ROA, ROE, and PM by consolidated data. It is also to be assumed that, to make the business more efficient, companies will in the future resort more to the concept of integrated reporting, as seen by the IIRC. The findings of this study enable companies to gain insight into the contribution of IR, especially in terms of enhancing the financial aspect, which is the most critical criteria for company survival. Also, they contribute to current literature given that research that includes EU countries, especially EU countries separately, is scarce. Therefore, no research had been conducted for Slovenia and Croatia before. Also, most studies do not conduct a thorough research of the reports in order to distinguish content elements applications, but rather look at the general application of the Framework or investigate only the influence of a single element. The study will hopefully encourage other scientists to conduct similar research on other EU countries and wider. To conduct an adequate benchmark analysis and to get an insight into the real level of integrated reporting development in Croatia and Slovenia, it is necessary to provide additional findings, since the few current ones only investigate Europe in general, and not its countries separately. Although the IR Framework has not yet fully come to life, it can be expected that, in the future, with increasing emphasis and set regulations, a larger number of companies will adopt its broad concept of reporting based on the values added concept. Considering that this research took into account the reports and financial data for the period before the Directive 2014/95/EU came into effect (i.e., 2017), further studies should focus on the after-period in order to establish whether Croatian and Slovenian companies have adopted the IR Framework in their 2017 or ongoing reports. Given that the Directive sets an obligation on disclosure of non-financial and diversity information by certain large undertakings and groups, including value creation through the business model, it can be assumed that the number of applications of the IR Framework, or at least its elements, will increase. Furthermore, a few previous research studies should have focused more on the implementation of the entire IR Framework, but by each content element and their influence on companies' performance. This would contribute more to the managers' awareness of the impact of information asymmetry that can reduce stakeholders' trust. Also, current research should be expanded further by looking into why companies in Croatia and Slovenia do not apply the IR Framework. This should especially apply to those companies that already use GRI standards. This could 
help practitioners to come to a common solution and simplify the application or IR. All of this could be considered as limitations of this research. Nevertheless, the sample used for this paper focuses only on the companies registered on the Croatian and Slovenian stock exchange. Consequently, the findings might not be able to generalize the entire population of the two countries. Further research should account for a much larger sample; for example, the thousand largest companies that are listed every year in the Croatian business magazine Lider.

\section{ACKNOWLEDGMENT}

This work is a result of the project - Unique information system for Measuring the Efficiency of Public Health Services at the RH Level (uniri-sp-drustv-18-51 1473) supported by the University of Rijeka.

\section{REFERENCES}

1. Adegboyegun, A.E. et al. (2020) „Integrated reporting and corporate performance in Nigeria: Evidence from the banking industry", Cogent Business \& Management, Vol. 7, No.1, doi: 10.1080/23311975.2020.1736866

2. Affan, M.V. (2019) „Integrated Reporting and Corporate Performance: Empirical Evidence of TheIIRC Framework Adoption“, Jurnal Ilmiah Bidang Akuntansi dan Manajemen, Vol. 16, No. 2, doi: 10.31106/jema.v16i2.2700

3. Albetairi, H.T.A., Kukreja, G., Hamdan, A. (2018) „Integrated Reporting and Financial Performance: Empirical Evidences from Bahraini Listed Insurance Companies", Accounting and Finance Research, Vol. 7, No. 3, pp. 102-110, doi: 10.5430/afr.v7n3p102

4. Alikaj, A., Nguyen, C.N., Medina, E. (2017) „Differentiating the impact of CSR strengths and concerns on firm performance: An investigation of MNEs and US domestic firms“, Journal of Management Development, Vol. 36, No. 3, pp.401-409, doi: 10.1108/JMD-04-2016-0058

5. Allouche, J., Laroche, P. (2005) "A meta-analytical investigation of the relationship between corporate social and financial performance", Revue de Gestion des Ressources Humaines, Vol. 57, pp. 18-41

6. American Institute of CPAs (AICPA) - The Chartered Institute of Management Accountants (CIMA) - Black Sun (BS)- The International Integrated Reporting Council (IIRC) (2016) Value of value: board-level insights, available at: http://integratedreporting.org/wp-content/uploads/2016/12/2016-Value-of-ValueBoard-Level-Insights.pdf

7. Appiagyei, K., Djajadikerta, H., Xiang, E. (2016) „Integrated Reporting and Firm Performance: A Research Framework", Proceedings of the ECU Business Doctoral and Emerging Scholars Colloquium, available at: http://ro.ecu.edu.au/ecuworkspost2013/2695/ 
8. Abreu, R., Almeida, R., Lopez, J. A. P. (2017) „Corporate social responsibility and performance: Evidence from the water industry", New Trends and Issues Proceedings on Humanities and Social Sciences, Vol. 4, No. 10, pp. 265-272.

9. Bagieńska, A. (2016) „Value Added Statement - A Relevant Instrument for Integrated Reporting“, Financial Internet Quarterly ,e-Finanse”, Vol. 12, No. 4, pp. 92-104, doi: 10.1515/f qf-2016-0011

10. Beurden, P.V., Gössling, T. (2008) "The worth of values: a literature review on the relation between corporate social and financial performance", Journal of Business Ethics, Vol. 82, No. 2, pp. 407-424, doi: 10.1007/s10551-008-9894-x

11. Brown, J., Dillard, J. (2014) "Integrated reporting: on the need for broadening out and opening up", Accounting, Auditing \& Accountability Journal, Vol. 27, No. 7, pp. 1120-1156, doi: 10.1108/AAAJ-04-2013-1313

12. Buallay, A. (2019) „Is sustainability reporting (ESG) associated with performance? Evidence from the European banking sector", Management of Environmental Quality: An International Journal, Vol. 30, No. 1, pp. 98-115, doi: 10.1108/MEQ12-2017-0149

13. Chen, L., Feldmann, A., Tang, O. (2015), The relationship between disclosures of corporate social performance", International Journal of Production Economics, Vol. 170, Part B, pp.445-456, doi: 10.1016/j.ijpe.2015.04.004

14. Chersan, I.C. (2015) „Study on practices and tendencies in integrated reporting, Audit Financiar, Vol. 9, No. 129, pp. 25-36.

15. Churet, C., Eccles, G.E. (2014) „Integrated Reporting, Quality of Management, and Financial Performance“, Journal of Applied Corporate Finance, Vol. 26, No. 1, pp.56-64, doi: 10.1111/jacf.12054

16. Da Silva Faria, M.J. (2016) „A New Form of Reporting For Companies. The Integrated Reporting", International journal of management and economics invention, Vol. 2 No. 11, pp. 1081-1091.

17. Dees, S (2019) „The influence of long-term orientation and integrated reporting on financial performance“, Radboud University Nijmegen School of Management, Nijmegen

18. De Villiers, C., Rinaldi, L., Unerman J. (2014) „Integrated Reporting: Insights, gaps and an agenda for future research", Accounting, Auditing \& Accountability Journal, Vol. 27, No. 7, pp. 1042-1067, doi: 10.1108/AAAJ-06-2014-1736

19. Dragu, I., Tiron-Tudor, A. (2014), „Research Agenda on Integrated Reporting: New Emergent Theory and Practice“, Procedia Economics and Finance, Vol. 15, pp.221-227, doi: 10.1016/S2212-5671(14)00488-2

20. Dragu, I.M., Tiron-Tudor, A. (2013) „The Integrated Reporting Initiative from an Institutional Perspective: Emergent Factors“, Procedia - Social and Behavioral Sciences, Vol. 92, pp.275-279, doi: 10.1016/j.sbspro.2013.08.672

21. Dube, V. (2017) „The association between integrated reporting and company financial performance: A graphical time-series approach“, Gordon Institute of Business Science, University of Pretoria, (Online), available at: http://hdl.handle.net/2263/64840 
22. Eccles, G.R., Krzus, P.M., Ribot, S. (2015) „Meaning and Momentum in the Integrated Reporting Movement", Journal of Applied Corporate Finance, Vol. 27, No. 2, pp.8-17, doi: 10.1111/jacf.12113

23. Eccles, G.R., Saltzman, D. (2011) „Achieving Sustainability Through Integrated Reporting“, Stanford Social Innovation Review, Summer 2011, available at: https://pdfs.semanticscholar.org/618f/901ec8d9c8b6dc62a3c0344bb303de86e981.p df

24. Elkington, J. (1997), ,, Cannibals with Forks:The Triple Bottom Line of 21st Century Business", Enter The Triple Bottom Line, Capstone, Oxford, available at: http://www.johnelkington.com/archive/TBL-elkington-chapter.pdf

25. Ernst \& Young (EY) \& International Integrated Reporting Council (IIRC) (2013) Value creation, background papaer, available at: http://integratedreporting.org/wpcontent/uploads/2013/08/Background-Paper-Value-Creation.pdf

26. Europska unija (EU) (2014) Direktiva 2014/95/eu Europskog parlamenta i vijeća od 22. Listopada 2014. O izmjeni Direktive 2013/34/EU u pogledu objavljivanja nefinancijskih informacija i informacija o raznolikosti određenih velikih poduzeća $i$ grupa, available at: http://eur-lex.europa.eu/legalcontent/HR/TXT/PDF/?uri=CELEX:32014L0095\& from=HR

27. Europska unija (EU) (2017), ,Smjernice za izvješćivanje o nefinancijskim informacijama ", available at: http://eur-lex.europa.eu/legalcontent/HR/TXT/PDF/?uri=CELEX:52017XC0705(01)\&qid=1508239676285\&fro $\mathrm{m}=\mathrm{EN}$

28. Flower, J. (2015) „,The international integrated reporting council: A story of failure“. Critical Perspectives on Accounting, Vol. 27, pp. 1-17, doi: 10.1016/j.cpa.2014.07.002

29. Freeman, R.E. (1984) „Strategic Management: A Stakeholder Approach“, Pitman, Boston

30. Haji, AA., Anifowose, M. (2016) „The trend of integrated reporting practice in South Africa: ceremonial or substantive?", Sustainability Accounting, Management and Policy Journal, Vol. 7, No. 2, pp. 190-224, doi: 10.1108/SAMPJ-11-20150106

31. Haji, AA., Anifowose, M. (2017) „Initial trends in corporate disclosures following the introduction of integrated reporting practice in South Africa", Journal of Intellectual Capital, Vol. 18, No. 2, pp. 373-399, doi: 10.1108/JIC-01-2016-0020.

32. Haller, A., van Staden C. (2014), ,The value added statement - an appropriate instrument for Integrated Reporting“", Accounting, Auditing \& Accountability Journal, Vol. 27 No. 7, pp.1190-1216, doi: 10.1108/AAAJ-04-2013-1307

33. Havlová, K. (2015), „What What Integrated Reporting Changed: The Case Study of Early Adopters“, Procedia Economics and Finance, Vol. 34, pp. 231-237, doi: 10.1016/S2212-5671(15)01624-X

34. Hurghiș, R. (2015) „Integrated reports and financial performance: an analysis“, EUFIN 2015, The 1th Workshop on European Financial Reporting, Paris, France.

35. International Integrated Reporting Council (IIRC) (2013) The International $\langle I R>$ Framework, Integrated Reporting $<I R>$, available at: 
http://integratedreporting.org/wp-content/uploads/2015/03/13-12-08-THEINTERNATIONAL-IR-FRAMEWORK-2-1.pdf

36. International Integrated Reporting Council and Black Sun (IIRC and Black Sun) (2014) Realizing the benefits: The impact of Integrated Reporting, available at: http://integratedreporting.org/wpcontent/uploads/2014/09/IIRC.Black_Sun_.Research.IR_.Impact.Single.pages.18.9 .14.pdf

37. Johari, J., Komathy (2019) „Sustainability Reporting and Firm Performance: Evidence in Malaysia“, International Journal of Accounting, Finance and Business (IJAFB), Vol. 4, No. 17, pp. 1-7.

38. Johner, R. (2016) „Integrated reporting: better than mere compliance“, $P w c$ Disclose:In the spotlight: Corporate reporting, No. 1, available at: https://disclose.pwc.ch/23/en/integrated-reporting-better-than-mere-compliance/

39. Lopes, I, Coelho, M (2018) „Engaged in integrated reporting? Evidence across multiple organizations“, European Business Review, Vol. 30 No. 4, pp. 398-426, doi: 10.1108/EBR-12-2016-01.

40. Margolis, J.D., Walsh, J.P. (2003) „Misery loves companies: rethinking social initiatives by business", Administrative Science Quarterly, Vol. 48, No. 2, pp. 268305, doi: $10.2307 / 3556659$

41. Marrone, A., Oliva, L. (2019) „The Level of Integrated Reporting Alignment with the IIRC Framework: Evidence from South Africa", International Journal of Business and Management, Vol. 15, No. 1, pp. 99-108, doi:10.5539/ijbm.v15n1p99

42. Matemane, R., Wentzel, R. (2019) „Integrated reporting and financial performance of South African listed banks", Banks and Bank Systems, Vol. 14, No. 2, pp. 128139, doi:10.21511/bbs.14(2).2019.11.

43. McWilliams, A., Siegel, D. (2000) „Corporate social responsibility and financial performance: correlation or misspecification?“", Strateg. Manag. J., Vol. 21, No. 5, pp. 603-609. doi: 10.1002/(SICI)1097-0266(200005)21:5<603::AIDSMJ101>3.0.CO;2-3

44. McWilliams, A., Siegel, D., (2001) „Corporate Social Responsibility: a theory of the firm perspective“ Acad. Manag. Rev,.Vol. 26, No. 1, pp. 117-127. doi: 10.5465/amr.2001.4011987

45. Milne, M.J., Gray, R. (2013) „W(h)ither ecology? The triple bottom line, the global reporting initiative, and corporate sustainability reporting“", Journal of Business Ethics, Vol. 118, No. 1, pp. 13-29, doi: 10.1007/s10551-012-1543-8

46. Moolman, J., Oberholzer, M., Steyn M. (2016) „The effect of integrated reporting on integrated thinking between risk, opportunity and strategy and the disclosure of risks and opportunities“, Southern African Business Review, Vol. 20, No. 1, pp.600627, doi: 10.25159/1998-8125/6065 https://www.ajol.info/index.php/sabr/article/view/151769/141381

Orlitzky, M., Schmidt, F.L., Rynes, S.L. (2003) "Corporate social and financial performance: a meta-analysis”, Organization Studies, Vol. 24, No. 3, pp. 403-441, doi: $10.1177 / 0170840603024003910$ 
47. Oshika, T., Saka, C. (2017) „Sustainability KPIs for integrated reporting“, Social Responsibility Journal, Vol. 13, No. 3, pp.625-642, doi: 10.1108/SRJ-07-20160122

48. Perera-Aldama, L., Zicari, A. (2012) „Value-added reporting as a tool for sustainability: a Latin American experience", Corporate Governance: The international journal of business in society, Vol. 12, No. 4, pp. 485 - 498, doi: $10.1108 / 14720701211267829$

49. Raimo, N., Zito, M., \& Caragnano, A. (2019) „Does national culture affect integrated reporting quality? A focus on GLOBE dimensions“" In 9th International Symposium on Natural Resources Management, Zaječar, Serbia.

50. Recognized reports, (Online) (2019), available at: http://examples.integratedreporting.org/recognized reports

51. Reuter, M., Messner, M. (2015) „Lobbying on the integrated reporting framework“, Accounting,Auditing \& Accountability Journal, Vol. 28 , No. 3, pp. 365 - 402, doi: 10.1108/AAAJ-03-2013-1289

52. Roca, L.C., Searcy. C. (2012) „An analysis of indicators disclosed in corporate sustainability reports“, Journal of Cleaner Production, Vol. 20, No. 1, pp. 103118, doi: 10.1016/j.jclepro.2011.08.002

53. Roth, H.P. (2014) „Is integrated reporting in the future?“, The CPA Journal, Vol. 84, No. 3, pp. 62-67.

54. Ruiz-Lozano, M., Tirado-Valencia, P. (2016) „Do industrial companies respond to the guiding principles of the Integrated Reporting framework? A preliminary study on the first companies joined to the initiative", Revista de Contabilidad-Spanish Accounting Review, Vol. 19, No. 2, July-December 2016, pp. 252-260, doi: 10.1016/j.rcsar.2016.02.001

55. Simnett, R., Huggins, A.L. (2015), „Integrated reporting and assurance: where can research add value?", Sustainability Accounting, Management and Policy Journal, Vol. 6, No. 1, pp. 29-53, doi: 10.1108/SAMPJ-09-2014-0053

56. Sofian, I. (2016) „The adoption of integrated reporting principles by the Romanian companies listed at the Bucharest Stock Exchange“, Audit Financiar, Vol. 15, No. 12, pp. 1335-1348, doi: 10.20869/AUDITF/2016/139/1335

57. Sofian, I. (2019) „Does an improved type of reporting lead to a better financial performance?", Accounting and Management Information Systems, Vol. 18, No. 1, pp. 73-100, doi:10.24818/jamis.2019.01004.

58. Solomon, J., Maroun, W. (2012) „Integrated Reporting: The Influence of King III on Social, Ethical and Environmental Reporting", The Association of Chartered Certified Accountants, London.

59. Sukhari, A., De Villiers, C. (2018) „The Influence of Integrated Reporting on Business Model and Strategy Disclosures", Australian Accounting Review, Vol. 29, No. 4, pp. 708-725, doi: 10.1111/auar.12264

60. Suttipun, M. (2017) „The effect of integrated reporting on corporate financial performance: Evidence from Thailand", Corporate Ownership \& Control, Vol. 15, No. 1, pp. 133-142, doi: 10.22495/cocv15i1art13.

61. The IIRC (Online) (2019), available at: https://integratedreporting.org/the-iirc-2/ 
62. Turturea, M. (2015) „Integrated reporting into practice-a ten year experience“, SEA-Practical Application of Sience, Vol. 3, No. 1(7), pp. 565-571, available at: http://seaopenresearch.eu/Journals/articles/SPAS_7_81.pdf

63. United Nations (UN) (1987) Report of the World Commission on Environment and Development- Our Common Future.

64. Velte, P., Stawinoga, M. (2016) „Integrated reporting: The current state of empirical research, limitations and future research implications", Journal of Management Control, Online paper, pp.1-46, doi:10.1007/s00187-016-0235-4

65. Veras Machado, M.A., da Silva Macedo, M.A., Reis Machado, M. (2015) „Analysis of the Relevance of Information Content of the Value Added Statement in the Brazilian Capital Markets", Revista Contabilidade \& Finanças - RC\&F, Vol. 26, No. 67, pp. 57-69, doi: 10.1590/1808-057x201512240

66. Vitolla, F., Raimo, N., Rubino, M. (2019) „Appreciations, criticisms, determinants, and effects of integrated reporting: A systematic literature review“", Corporate Social Responsibility and Environmental Management, Vol. 26, No. 2, pp. 518 528, doi: 10.1002/csr.1734

67. Vitolla, F, Raimo, N, Rubino, M, Garzoni, A. (2019) „The impact of national culture on integrated reporting quality. A stakeholder theory approach“, Bus Strat Env., Vol. 28, No.8, pp. 1558-1571, doi:10.1002/bse.2332

68. Vitolla, F., Salvi, A., Raimo, N., Petruzzella, N., Rubino, M. (2019) „The impact on the cost of equity capital in the effects of integrated reporting quality", Business Strategy and the Environment, Online version, pp. 1-11, doi: 10.1002/bse.2384

69. Vitezić, N. (2010) „Corporate Sustainability and Triple Bottom Line: Croatian experience“, Int.J.Trade and Global Markets, Vol. 3, No.1, pp.68-81.

70. Vitezić, N. (2011) „Correlation between social responsibility and efficient performance in Croatian enterprises“, Zbornik radova Ekonomskog fakulteta $u$ Rijeci: časopis za ekonomsku teoriju i praksu, Vol.29 No.2, pp.423-442.

71. Vitezić, N., Petrlić, A. (2018) „Integrated Reporting - Concept and Impact on Performance of Croatian Companies", "Journal of Accounting and Management, Vol. 08, No. 1; pp. 71-82.

72. Waddock, S.A., Graves, S.B. (1997) „The corporate social performance-financial performance link“, Strategic Management Journal, Vol. 18, No. 4, pp.30-319, doi: 10.1002/(SICI)1097-0266(199704)18:4<303::AID-SMJ869>3.0.CO;2-G

73. Weber, O., Koellner, T., Habergger, D., Steffensen, H., Ohnemus, P. (2008) „The relation between the GRI indicators and the financial performance of firms", Progress in Industrial Ecology-An International Journal, Vol. 5, No. 3, pp. 236254, doi: 10.1504/PIE.2008.019127

74. Welch, I. (2013) ,, The benefits and downsides of integrated reporting “, (Online), available at: http://www.theaccountant-online.com/comments/the-benefits-anddownsides-of-integrated-reporting

75. Wen, L.P., Kiew Heong, A.Y. (2017) „Integrated Reporting and Financial Performance: Evidence from Malaysia“, Management \& Accounting Review, Vol. 16, No. 2, December, pp. 101-130, doi: 10.24191/mar.v16i2.647. 
76. Wild, S., van Staden, C. (2013) „Integrated Reporting: Initial analysis of early reporters - an Institutional Theory approach", 7th Asia Pacific Interdisciplinary Accounting Research Conference, pp. 26-28. Kobe. 


\title{
POVEĆAVA LI EFIKASNOST PRIMJENU INTEGRIRANOG IZVJEŠTAVANJA?
}

\begin{abstract}
Antonija Petrlić \& Neda Vitezić

\section{Sažetak}

Stalni zahtjevi dionika za detaljnijim i transparentnjim izvještavanjem doveli su do razvoja novog okvira za izvještavanje. To je takozvani međunarodni Okvir integriranog izvještavanja prema kojem tvrtke izvještavaju o financijskim te nefinancijskim aspektima poslovanja $i$, važnije, prikazuju način stvaranja vrijednosti putem postavljenog poslovnog modela kroz kratkoročno, srednjoročno i dugoročno razdoblje. Budući da se još uvijek smatra novim alatom društveno odgovornog izvještavanja, postavlja se pitanje njegove prepoznatljivosti i razine njegove provedbe te utjecaja na poslovanje. Stoga ovaj rad analitički razlaže ukupni koncept integriranog izvještavanja i njegovu povezanost s načelom efikasnosti kao temelja procesa kreiranja vrijednosti. Glavni cilj rada bio je istražiti trenutnu primjenu koncepta integriranog izvještavanja u poduzećima Republike Hrvatske i Republike Slovenije u razdoblju od 2011. do 2016. godine te utvrditi utječe li veći stupanj efikasnosti na implementaciju integriranog načina izvještavanja $i$ društveno odgovornije poslovanje. Pritom je korištena meotda istraživanja putem interneta, deskriptivna statistika i neparametrijska metoda testiranja hipoteze. Iako su rezultati pokazali nizak stupanj primjene međunarodnog okvira integriranog izvještavanja, empirijski dio pokazuje da veća razina efikasnosti potiče tvrtke na provedbu društveno odgovornijeg poslovanja kroz prezentaciju ekonomskih, ekoloških i socijalnih aspekata poslovanja.
\end{abstract}

Ključne riječi: efikasnost poslovanja, dodana vrijednost, integrirano izvještavanje, Hrvatska, Slovenija. 